\title{
Third-Party Borehole Seismic Experiments during the Ocean Drilling Program
}

\author{
by Ralph A. Stephen, Stephen A. Swift, S. Thompson Bolmer, and Hartley Hoskins
}

\section{Introduction}

The first borehole seismic experiments on DSDP and ODP were two-ship Oblique Seismic Experiments (Stephen, 1979; Stephen, et al., 1979, 1980; Swift, et al., 1988). By recording on the drill ship and shooting explosives out to ranges of $8 \mathrm{~km}$, the upper $1.5 \mathrm{~km}$ of the upper crust (Layer 2) adjacent to the borehole could be imaged (Fig. 1; Stephen and Harding, 1983). Azimuthal anisotropy (Stephen, 1981, 1985) and lateral heterogeneity (Stephen, 1988; Swift and Stephen, 1989) could also be studied by shooting circles of shots at a fixed range from the borehole.

\section{Western Atlantic South of Bermuda (DSDP Hole 418, Leg 102)}

Third-party borehole seismic experiments on the Ocean Drilling Program began with an Oblique Seismic Experiment at Site 418 in the Western Atlantic south of Bermuda on Leg 102. The experiment confirmed the velocity structure of upper Layer 2 including azimuthal anisotropy and azimuthdependent scattering. It is interesting to note that travel-

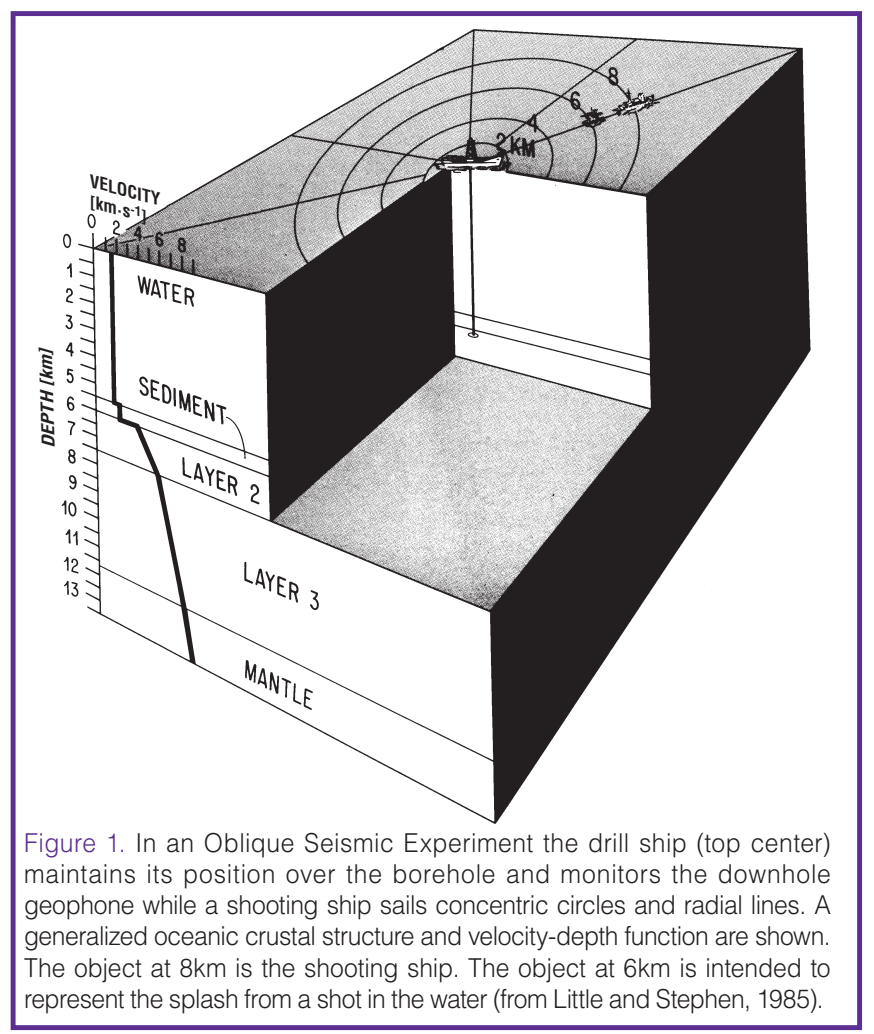

time and amplitude data from two Oblique Seismic Experiments on 110-ma crust in the slow-spreading western North Atlantic and fast-spreading northwestern Pacific show that compressional velocities within layer 2 are, within experimental error, identical (Kong et al., 1985).

\section{Southwest Indian Ridge (Hole 735B, Leg 118)}

Normal incidence Vertical Seismic Profiles (VSP) were carried out on ODP Legs 104, 109, and 111 before the VSP at Hole 735B on Leg 118 on the Southwest Indian Ridge. This experiment measured velocities corresponding to Layer 3 which was consistent with the gabbroic petrology of the cores. Anomalously high attenuation was also observed, prompting the hypothesis that the gabbro cored may not actually represent the bulk of Layer 3 material.

\section{Argo Abyssal Plain (Hole 765, Leg 123)}

In thick sedimentary sequences VSPs can be very useful in correlating the drilling results with the seismic reflection profiling results. This was demonstrated on ODP Leg 123 which drilled in the Argo Abyssal Plain (Leg 123 Shipboard Scientific Party, 1990a; b). VSPs were also carried out on ODP Legs 127/128, 129, 131, and 146.

\section{Costa Rica Rift (Hole 504B, Legs 111 and 148)}

The VSP data acquired at Hole 504B in the eastern equatorial Pacific on Leg 148 helped to constrain the velocitydepth structure at the site (Swift, et al., 1996, 1998a, 1998b) and showed that upper Layer 3 at this site, at a depth of over $2 \mathrm{~km}$ into the crust, did not consist of gabbros but rather consisted of the lower portions of the sheeted dykes (Detrick et al., 1993). VSPs were also carried out on Leg 156.

\section{Gas Hydrates on the Blake Ridge (Holes 994, 995, and 997; Leg 164)}

Both offset and normal incidence VSPs were run on Leg 164 to study the seismic velocity structure of gas hydrates on the Blake Ridge, offshore South Carolina. Seismic velocities measured in three drill holes through the gas hydrate deposit indicated that substantial free gas exists to at least $250 \mathrm{~m}$ beneath the bottom-simulating reflector (BSR; Holbrook 


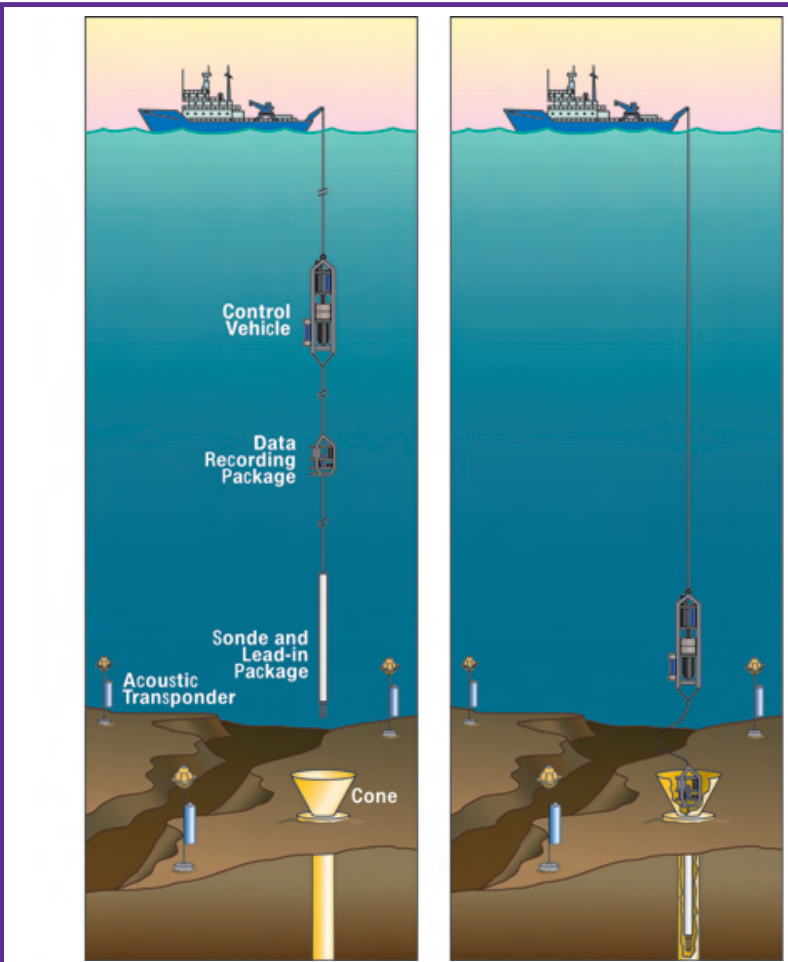

Figure 2. In the Wireline Re-entry System, a borehole sonde, data recording package, and control vehicle are suspended from a conventional research vessel on coaxial or fiber-optic cable (left). The control vehicle, navigated within a network of acoustic transponders, is used to guide the sonde into the borehole. The sonde is lowered into the borehole until the data recording package lands in the re-entry cone (right). When the seafloor and subseafloor systems are operating properly, the control vehicle is disconnected from the data recoding package and is recovered back onboard the ship. The borehole system acquires data autonomously for up to a year until the system is recovered by grappling. From Stephen, et al., 2003.

et al., 1996). Both methane hydrate and free gas exist even where a clear BSR is absent. The low reflectance, or blanking, above the BSR is caused by lithologic homogeneity of the sediments rather than by hydrate cementation.

\section{Seismology with the Wireline Re-entry System}

The ODP era also saw the development of systems for reentering boreholes from conventional research vessels and submersibles after the drill ship left the site (Fig. 2; Legrand et al., 1989; Montagner et al., 1994a; Spiess et al., 1992). Borehole seismic experiments and installations that used wireline re-entry technology were carried out in DSDP Holes 534 (Blake-Bahama Basin;Bradley et al., 1997; Stephen et al., 1994) and 396 (Mid-Atlantic Ridge at 23degrees north; Montagner et al., 1994a) and in ODP Hole 843B (south of Oahu; Stephen et al., 2003). The latter experiment (the Ocean Seismic Network Pilot Experiment) carried out a test of three configurations of broadband seafloor seismic installation in preparation for extending the Global Seismic Network to the deep ocean.

\section{Broadband Borehole Seismology}

Anew innovation on ODP was the deployment of broadband seismometers in boreholes (Suyehiro et al., 2006). Whereas the conventional VSPs and offset VSPs mentioned above operate in the frequency range of $1-100 \mathrm{~Hz}$ (similar to the band used for reflection and refraction seismology), broadband seismometers are used in earthquake seismology and operate in the frequency range of $0.001-10 \mathrm{~Hz}$. The first broadband borehole seismometer test was carried out from the drill ship on Leg 128 in the Japan Sea in 1989 (Kanazawa et al., 1992; Suyehiro et al., 1992). The first submersibleassisted broadband borehole seismometer test was carried out on the Mid-Atlantic Ridge (Montagner et al., 1994a, 1994b). On the Ocean Seismic Network Pilot Experiment a broadband borehole sensor in ODP Hole $843 \mathrm{~B}$ was compared with a shallow buried and a seafloor seismometer for a period of over three months (Stephen et al., 2003). Subsequently, four permanent broadband borehole seismic observatories were installed in the western Pacific and Japan Trench on Legs 186, 191 and 195 (Araki 1999; Araki et al. 2004; Suyehiro et al., 2002). Three other boreholes have been drilled specifically for borehole seismic installations: at the Ninety-east Ridge, near the Hawaii-2 Observatory, and in the equatorial Pacific.

\section{Acknowledgements}

RAS would like to thank the Earthquake Research Institute at the University of Tokyo for a six-month Visiting Professorship during which this synthesis was carried out.

\section{References}

Araki, E., 1999. Geophysical nature of broadband seismic signals in deep oceans. PhD thesis, University of Tokyo, Tokyo.

Araki, E., Shinohara, M., Sacks, S., Linde, A., Kanazawa, T., Shiobara, H., Mikada, H., and Suyehiro, S., 2004. Improvement of seismic observation in the ocean by use of seafloor boreholes. Bull. Seism. Soc. Am., 94:678-690.

Bradley, C.R., Stephen, R.A., Dorman, L.M., and Orcutt, J.A., 1997. Very low frequency $(0.2-10.0 \mathrm{~Hz})$ seismoacoustic noise below the seafloor. J. Geophys. Res., 102(11):703-711,718, doi:10.1029/96JB3183.

Detrick, R.S., Collins, J.A., Stephen, R.A., and Swift, S.A., 1994. In situ evidence for the nature of the seismic layer $2 / 3$ boundary in oceanic crust, Nature, 370:288-290, doi:10.1038/ $370288 \mathrm{a} 0$.

Holbrook, W.S., Hoskins, H., Wood, W.T., Stephen, R.A., Lizarralde, D., and Leg 164 Science Party, 1996. Methane hydrate and free gas on the Blake Ridge from vertical seismic profiling. Science, 273:1840-1843, doi: 10.1126/ science.273.5283.1840.

Kanazawa, T., Suyehiro, K., Hirata, N., and Shinohara, M., 1992. Performance of the ocean broadband downhole seismometer at site 794. In K. Tamaki, Suyehiro, K., Allan, J., McWilliams, M., et al. (Eds.), Proceedings of the Ocean Drilling Program, Scientific Results 127/128 Part 2, College Station, Texas (Ocean Drilling Project), 1157-1171.

Kong, L., Brocher, T.M., and Stephen, R.A., 1985. Spreading rate independence of oceanic seismic layer 2. Geophys. Res. Lett., 12:219-222. 
Leg 123 Shipboard Scientific Party, 1990a. Explanatory Notes. In Ludden, J.N., Gradstein, F.M., et al., (Eds.), Proceedings of the Ocean Drilling Program, Initial Report. College Station, Texas (Ocean Drilling Program), 27-59.

Leg 123 Shipboard Scientific Party, 1990b. Site 765., In Ludden, J.N., Gradstein, F.M., et al (Eds.), Proceedings of the Ocean Drilling Program, Initial Report. College Station, Texas (Ocean Drilling Program), 63-267.

Legrand, J., Echardour, A., Floc'h, H., Floury, L., Gieskes, J., Harmegnies, F., Loaec, G., Pozzi, J.-P., Raer, Y., and Stephen, R., 1989. Campagne FARE: Wireline reentry of DSDP Hole 396B using the NADIA system. EOS Trans. Am. Geophys. Union, 70:729-730, 741.

Little, S.A. and Stephen, R.A., 1985. Costa Rica Rift borehole seismic experiment, Deep Sea Drilling Project Hole 504B, Leg 92. Init. Repts. DSDP, 83:517-528.

Montagner, J.P., Karczewski, J.-F., Romanowicz, B., Bouaricha, S., Lognonne, P., Roult, G., Stutzmann, E., Thirot, J.-L., Brion, J., Dole, B., Fouassier, D., Koenig, J.-C., Savary, J., Floury, L., Dupond, J., Echardour, A., and Floc'h, H., 1994a. The French Pilot Experiment OFM-SISMOBS: first scientific results on noise level and event detection. Physics of the Earth and Planetary Interiors, 84:321-336, doi: 10.1016/003 1/9201(94)90050-7.

Montagner, J.P., Romanowicz, B., and Karczewski, J.-F., 1994b. A first step toward an oceanic geophysical observatory. EOS Trans. Am. Geophys. Union, 75:150-151, 154.

Spiess, F.N., Boegeman, D.E., and Lowenstein, C., 1992. First oceanresearch-ship-supported fly-in re-entry to a deep ocean drill hole. Mar. Tech. Soc. J., 26:3-10.

Stephen, R.A., 1979. The oblique seismic experiment in oceanic crust - equipment and technique. Mar. Geophys. Res., 4:213-226, doi: 10.1007/BF00286406.

Stephen, R.A., 1981. Seismic anisotropy observed in upper oceanic crust. Geophys. Res. Lett., 8:865-868.

Stephen, R.A., 1985. Seismic anisotropy in the upper oceanic crust. J. Geophys. Res., 90:(11):383-311, 396.

Stephen, R.A., 1988. Lateral heterogeneity in the upper oceanic crust at DSDP Site 504. J. Geophys. Res., 93:6571-6584.

Stephen, R.A., and Harding, A.J., 1983. Travel time analysis of borehole seismic data. J. Geophys. Res., 88:8289-8298.

Stephen, R.A., Koelsch, D., Berteaux, H., Bocconcelli, A., Bolmer, S., Cretin, J., Etourmy, N., Fabre, A., Goldsborough, R., Gould, M., Kery, S., Laurent, J., Omnes, G., Peal, K., Swift, S., Turpening, R., and Zani, C., 1994. The Seafloor Borehole Array Seismic System (SEABASS) and VLF Ambient Noise. Mar. Geophys. Res., 16:243-286, doi: 10.1007/BF01224745.

Stephen, R.A., Louden, K.E., and Matthews, D.H., 1979. The oblique seismic experiment on Deep Sea Drilling Project leg 52, In Donnelly, T., Francheteau, J., Bryan, W., Robinson, P., Flower, M., and Salisbury, M. (Eds.), Initial Reports of the Deep Sea Drilling Project, 51-53, Washington, DC (U.S. Government Printing Office), 675-704.

Stephen, R.A., Louden, K., and Matthews, D.H., 1980. The oblique seismic experiment on DSDP Leg 52. Geophys. J. R. Astron. Soc., 60:289-300.
Stephen, R.A., Spiess, F.N., Collins, J.A., Hildebrand, J.A., Orcutt, J. A., Peal, K.R., Vernon, F.L., and Wooding, F.B., 2003. Ocean seismic network pilot experiment. Geochem. Geophys. Geosyst., 4:1092, doi: 1010.1029/2002GC000485.

Suyehiro, K., Araki, E., Shinohara, M., and Kanazawa, T., 2002. Deep sea borehole observatories ready and capturing seismic wavesin the Western Pacific.EOSTransactions (Supplement), 83:621, 624-625, doi: 10.1029/2002EO000420.

Suyehiro, K., Kanazawa, T., Hirata, N., Shinohara, M. and Kinoshita, H., 1992. Broadband downhole digital seismometer experiment at Site 794: A technical paper, In Tamaki, K., Suyehiro, K., Allan, J., McWilliams, M., et al. (Eds.), Proceedings of the Ocean Drilling Program, Scientific Results, College Station, Texas (Ocean Drilling Program), 1061-1073.

Suyehiro, K., Montagner, J.-P., Stephen, R.A., Araki, E., Kanazawa, T., Orcutt, J., Romanowicz, B., Sacks, S., and Shinohara, M., 2006. Ocean seismic observatories. Oceanography, 19:144149.

Swift, S.A., and Stephen, R.A., 1989. Lateral heterogeneity in the seismic structure of upper oceanic crust, Western North Atlantic. J. Geophys. Res., 94:9303-9322.

Swift, S.A., Hoskins, H., and Stephen, R.A., 1996. Vertical seismic profile into upper oceanic crust at Hole 504B, In Alt, J.C., Kinoshita, H., Stokking, L.B., Michael, P.J., et al. (Eds.), Proceedings of the Ocean Drilling Program, Scientific Results, Washington, DC (U.S. Government Printing Office), 339347.

Swift, S.A., Kent, G.M., Detrick, R.S., Collins, J.A., and Stephen, R.A., 1998a. Oceanic basement structure, sediment thickness, and heat flow near Hole 504B. J. Geophys. Res., 103:1537715391.

Swift, S.A., Lizarralde, D., Hoskins, H., and Stephen, R.A., 1998b. Seismic attenuation in upper oceanic crust at Hole 504B. J. Geophys. Res., 103:27193-27206.

Swift, S.A., Stephen, R.A., and Hoskins, H., 1988. Structure of upper oceanic crust from an Oblique Seismic Experiment at site 418A, Western North Atlantic, In Salisbury, M.H., Scott, J.H., et al. (Eds.), Proceedings of the Ocean Drilling Program, Scientific Results, Wasthington, DC (U.S. Government Printing Office), 97-113.

\section{Authors}

Ralph A. Stephen, Department of Geology and Geophysics, Woods Hole Oceanographic Institution, Clark South 282, MS\#24, Woods Hole, Mass. 02543, U.S.A., e-mail: rstephen@ whoi.edu

Stephen A. Swift, Department of Geology and Geophysics, Woods Hole Oceanographic Institution, Clark South 286A, MS\#24, Woods Hole, Mass. 02543, U.S.A.

S. Thompson Bolmer, Department of Geology and Geophysics, Woods Hole Oceanographic Institution, Clark South 286B, MS\#24, Woods Hole, Mass. 02543, U.S.A.

Hartley Hoskins, Computer and Information Services, Department of Geology and Geophysics, Woods Hole Oceanographic Institution, Woods Hole, Mass. 02543, U.S.A. 